\title{
Identifying the Influential Factors Enriching the Experiences of Visitors of Touristic Religious Sites: The Case Study of Al-Khandaq Battle Site
}

\author{
Mohamed Saleh Amer \\ Urban and Regional Planning Program, Faculty of Built Environment and Surveying, Universiti Teknologi Malaysia 81310 UTM Johor Bahru, Johor
}

Abdullah Saeed Karban and Abdulrahman Abdulaziz Majrashi

Department of Islamic Architecture, College of Engineering and Islamic Architecture, Umm Al Qura, Mecca, Saudi Arabia

Mohammad Rafee Majid and Abba Saleh

Urban and Regional Planning Program, Faculty of Built Environment and Surveying, Universiti Teknologi Malaysia 81310 UTM Johor Bahru, Johor

\begin{abstract}
Enriching visitors' experiences at religious, historical sites (RHS) is getting more attention than before. This research aims to identify and investigate the influential factors enriching the visitors' experience at such a site, using Al-Khandaq battle site as the case study. Forty-two respondents were interviewed at the site and NVivo 12 pro software was used to code and analyze the responses. The study explored tourist motivations, expectations, and perceptions as the guiding constructs in detailed qualitative analysis. Foremost, learning, reliving the experience of the events of the battle, and Islamic values were the primary motivation to the historic site visitation. Next, findings reveal the extent to which tourists' expectations can be met through the availability of an open museum, accessibility, and the spatial and experiential simulation of the ancient AlKhandaq path. Lastly, the need to reconstruct the historical site in spatial planning and experiential dimensions formed the main thrust of the element of visitors' perception. Based on the foregoing, the study recommends that Al-Khandaq site should be developed traditionally as an open museum, displaying both religious and historical elements of the battle with emphasis on the visual connection to the Prophet's mosque.
\end{abstract}

\section{Article History}

Received : 12 September 2020

Received in revised form : 17 March 2021

Accepted : 18 March 2021

Published Online : 30 April 2021

\section{Keywords:}

Visitors Experiences; Religious Historical Sites; Al-Khandaq Battle; Tourists Perception; Tourist Motivation Values

Corresponding Author Contact:

Saleh1983@graduate.utm.my

DOI: $10.11113 /$ ijbes.v8.n2.703

(C) 2021 Penerbit UTM Press. All rights reserved

\section{Introduction}

Travel is essential for economic, social, and religious activities and tourism resulting from travel plays a significant role in countries' prosperity (Baggio, 2008; Frias et al., 2015). Many countries aim to support their economies by enriching tourists' experiences to attract more visitors and repeats from satisfied visitors. Enriching the tourist experience is positively related to improving tourist satisfaction and revisit intentions (Chen et al., 2020; Al-Ghamdi et al., 2021). Tourism also integrates a wide range of stakeholders (Costa \& Baggio, 2009; Frias et al., 2015). Budeanu (2007) and Moscardo \& Murphy (2014) suggest that tourism is a product that aims to fulfill tourist needs; therefore, it has been studied from providers and consumers (tourists) point of view. 
In this regard, enriching the tourist experience will benefit all stakeholders. Identifying some basic concepts such as tourist destination, tourism product, and point of interest is essential. Tourist destinations are tourist attractions that refer to a set of economic, cultural, and social events complemented by a set of supported infrastructures (Cohen et al., 2014). The complexity of tourism attraction can be reflected through a focus on the process of tourists' decisions. However, not enough research has been conducted on developing tourism attractions based on these decisions. Cohen et al. (2014) reviewed several studies about tourist behavior in the process of decision-making, and they suggest that tourists' decision process takes place independent of other consumption decisions. The tourists' decisions can only be elicited through less-structured methodologies involving narrative accounts of actions and activities (Zhang et al., 2020). Therefore, several have suggested conducting more studies on tourists' decisions.

Much of the tourism research appears to rest on the assumption that tourists' decisions are previously planned (Hyde \& Lawson, 2003; Bargeman \& Poel, 2006). As most existing research on tourists' decisions assume previously planned decisions, their decisions and their implications for enriching tourists' experiences are in urgent need of research. Therefore, this study investigates the influential factors on enriching visitor experiences of touristic religious sites.

The Kingdom of Saudi Arabia is blessed with many of the distinctive historical religious sites associated with events of the biography of the Prophet Mohamed (PBUH). However, many of these sites are not adequately included among the visiting places. For example, given the numerous positive contributions of Al-Khandaq battle as highlighted in both the religion and history of Islam, the site where the battle took place is however, not substantially captured in the list of the preferred sites by many.

This study's main objective is to identify the influential factors that enrich the tourists' experience at religious, historical sites by investigating tourists' motivations, expectations, and perceptions of Al-Khandaq battle site. The investigation of these factors helps identify the key issues influencing tourists' decisions to visit religious, historical sites in Saudi Arabia, particularly around Makkah and Madinah cities.

Many researchers investigated various factors that influence tourists' decisions, which in turn helps enrich their visiting experiences at war heritage sites (Alabau-Montoya \& Ruiz-Molina, 2020) and touristic religious sites (Correia \& Kozak, 2016; Hassani \& Moghavvemi, 2019; Juhanda, 2019). Previous studies show that three dominant factors influencing tourists' decisions: motivations, expectations, and perceptions. This study reviews the definitional issues for each factor for the essential contemporary factors impacting tourists' experience.

\section{Visitors Motivations}

Motivation is an essential factor in marketing decisions and environmental developments. Therefore, academics, researchers, and developers give great attention to understanding visitors' motivation (Correia \& Kozak, 2016; Giddy \& Webb, 2018; McIntosh \& Thyne, 2005; Paker \& Vural, 2016). Motivation refers to an individual's psychological and biological needs that drive a person's behavior and activities (Cohen et al., 2014; Eccles \& Wigfield, 2002; Yawson et al., 2009). Due to the importance of motivation, several studies have developed several theories or models to explain the concept of motivation (Cohen et al., 2014). For example, in 1997, Gnoth precisely differentiates between motives and motivations, where motives refer to the persons permeant activities, recurring on a cyclical basis (behaviorist approach), and motivations refer to preferences of a specific object (cognitivist approach) (Gnoth, 1997). In contrast, McCabe (2001) suggested that a visitor's motivation is characterized by a combination of behaviorist and cognitivist approaches (McCabe, 2001).

However, to date, there is no general agreement about the concept of motivation, and scholars still view the two concepts of motivation as one (Cohen et al., 2014). The push-pull is a simple and intuitive approach that is most commonly applied for explaining motivations to profile visitors (Said \& Maryono, 2018). Visitors are pushed by their needs and pulled by destination characteristics (Battour et al., 2017). This process is influenced by several factors such as involvement, perception, expectation, and emotion (Battour et al., 2017; Pestana et al., 2019; Said \& Maryono, 2018). Most studies that discuss theories of visitors' motivations were either conceptual or limited in scope and sample size (Battour et al., 2017; Fernández-Morales et al., 2016; Juhanda, 2019; McCabe, 2001; Said \& Maryono, 2018). Researchers in tourism have also been adopting the motivation theories with four structural factors, including personal seeking, intrapersonal seeking, personal escape, and intrapersonal escape. These factors function as a salient intrinsic for tourism motivational behavior (Cohen et al., 2014; Eccles \& Wigfield, 2002; Lai, 2011).

However, the relationship between motivation and visitor's behavior, such as expectation and perception, has been conceptualized and validated (Cohen et al., 2014). On the other hand, some studies focus on the formation of motivation, such as values, in order to understand what motivates visitors (Eccles \& Wigfield, 2002; Karban et al., 2017; Rosyada et al., 2018). The relationships between motivation and values and affective constructs such as expectation and perception remain the cornerstone of developing tourism activities and locations (Zakariya et al., 2020).

\section{Visitors Expectations}

Understanding consumer and visitor expectations play a vital role in satisfying their desires (de Rojas \& Camarero, 2008). Expectation refers to consumers' predictive needs and what consumers feel, wish or perceive to get from the provider (Cohen et al., 2014; Pons et al., 2016). In other words, the expectation is what the consumer wants to get. Also, consumer expectations represent the quality anticipated by customers when assessing service and product attributes (Allen, 2016; de Rojas \& Camarero, 2008). Expectations can, therefore, be of different types, such as outcomes, predictive, ideal, and experience-based expectations (Cohen et al., 2014). All these types are somehow intertwined with each other and are widely applied in tourism. Therefore, the 
researchers will use some of them as an approach to understanding the visitors' expectations for the Al-Khandaq battle.

For instance, outcomes expectation refers to the estimation of outcomes when assessing a given behavior (Cohen et al., 2014), while predictive expectations are the consumer's prediction about what they perceive to get based on their actions or behaviors (Thai, 2015; Zeithaml et al., 1993). Thus, expectations may be fulfilled or unfulfilled or exceeded what is expected, influencing visitor satisfaction and enriches their experience. Therefore, the expectancy theory can be considered to positively enrich the visitor experience, which meets or exceeds visitors' expectations (Hassani \& Moghavvemi, 2019; Lunenburg, 2011; Rahman, 2014).

Notable omissions in tourist literature is the investigation of the consistency of visitor expectations over time by analyzing the service, which is met and influenced by visitor demographics, which has also been discussed in this paper.

\section{Visitors Perceptions}

Perception refers to what consumers expect or imagine. It is usually shaped or generated by familiarity, experience, values, and motivations (Cohen et al., 2014; Correia \& Kozak, 2016; Kala, 2008). According to the perception theory taken from cognitive psychology, work on customer preferences attempts to examine cognitive elements in the perceptual phase, often at the cost of affective elements, without proper recognition of the interplay between cognitive and affective aspects (Bian \& Moutinho, 2015; Dimanche \& Havitz, 1995; Poor, 2014; Rahman, 2014).

Variances of perceptions contribute to differences in cognitive or behavioral motivational values; a core consequence for tourism is that beliefs such as motivation and actions are vital to creating tourist interest, the identity of destination and quality of service. Destination perception appears to be a significant area of study in perceptions-related tourism and customer behavior research (AlsInI et al., 2019; Qurashi, 2018; Rahman, 2014; Stylidis et al., 2014). In addition, the quality of perceived services is considered an essential factor in understanding visitor perception in tourism research (Cohen et al., 2014).

Thus, the researchers can differentiate between visitors expected and perceived quality. Recently, several studies in heritage and religious tourism, perceptions research in tourism often focus on examining ethical, historical, and religious perceptions of visitors (Griffin \& Raj, 2017; Juhanda, 2019; Raj \& Bozonelos, 2015). For example, Alsini et al. (2019) concentrate on tourists' perceptions of religious tourism in Saudi Arabia. The impacts of Islamic life and beliefs, provided services, destination quality, and Religious tourist loyalty are factors that could exploit event attributes to form positive consumer perceptions (Alsini et al., 2019).

However, various studies indicate that understanding and considering visitor perceptions would contribute to better social, political, environmental, technological, and service-related issues (Al-Ghamdi et al., 2021; Cohen et al., 2014)). Therefore, this research seeks to understand the perception of Al-Khandaq battle visitors to provide a proper environment and services that exceed their expectations.

\section{Heritage and Religious Tourism}

Heritage and religious tourism refer to tourism services or locations that provide historical, cultural, and heritage experiences that are mostly rooted in religious sources. The concern of studying religious heritage tourism stems from the importance of this type of tourism to provide visitors' needs and expectations and the importance of these visitors to the local economy. According to Chandler \& Costello (2002), the importance of heritage tourism stems from the visitors' revenues to the local economy. Thus, visitors to historical sites are considered very important to the tourism and recreation industry (Chandler \& Costello, 2002; Griffin \& Raj, 2017), as these visitors to historical and religious sites tend to vary somewhat from visitors to new cities or nature (Li \& McKercher, 2016; Sharpley, 2018).

Visitors of historical and religious sites are also more likely to participate in passive recreation activities such as worshipping, welfare practicing, sightseeing, learning, wildlife watching, and relaxing (Ahmed, 1992; Chandler \& Costello, 2002; Mujtaba, 2016; Karban et al., 2018) Juhanda, 2019). As Chandler \& Costello (2002) reported, historic sites' visitors are mostly older people who tend to spend more money and are more likely to use different sources to gather information about trip planning and destination selection.

\section{Methodology}

\subsection{Description of Study Area}

The study area is Al-Madinah Al-Munawwarah, located in the Eastern Part of Al Hijaz Region in the northwestern part of Saudi Arabia at latitude $24.2806^{\circ} \mathrm{E}$ and longitude $39.366^{\circ} \mathrm{N}$. The city is about $150 \mathrm{~km}$ away from Yanbu city on the Red Sea coast to the west. The latter is the sea gate for the visitors of the city. AlMadinah Al-Munawwarah is $400 \mathrm{~km}$ away from Jeddah, the main port, and $980 \mathrm{~km}$ away from Riyadh, the capital of the Kingdom (Figure 1). It is located in a hot tropical region and is influenced by the Mediterranean region in the north and the south's tropical season region. Madinah is surrounded mostly by mountains and its height above sea level is between (590-620 meters). The Medina area is about 589 square kilometers, of which 99 square kilometers are occupied by the urban area (Bob et al., 2016).

Al-Madinah Al-Munawwarah is considered the second most important Islamic city after Holy Makkah. Its importance is derived from the presence of the Prophet's Mosque; Al-Madinah is also one of the holy cities that non-Muslims are not allowed to visit. AlMadinah occupies a natural hillside basin more than 600 meters above sea level. The city is surrounded by a group of volcanic mountains, except for its northern sides.

The Battle of Al-Khandaq is considered one of the most important events of the Prophet's biography, which embodies the most important meanings of patience and sacrifice. The site is filled with 
lessons and sermons; its events are glossy pages, which are passed on from generation to generation (Figure 1).

The victory in the hearts of Muslims is linked to the location in which it occurred. The trench area is one of the legitimate places to visit and features Al-Fateh Mosque, from which Prophet Mohammed, (PBUH) called for victory over various groups.
Today, it is called the seven mosques area. One of the most critical landmarks, it contains a small group of mosques whose exact number is six, not seven; however, it is famous due to the addition of the Qiblatan Mosque within these mosques, because whoever visits it also visits that mosque on the same trip, bringing the total number to seven.

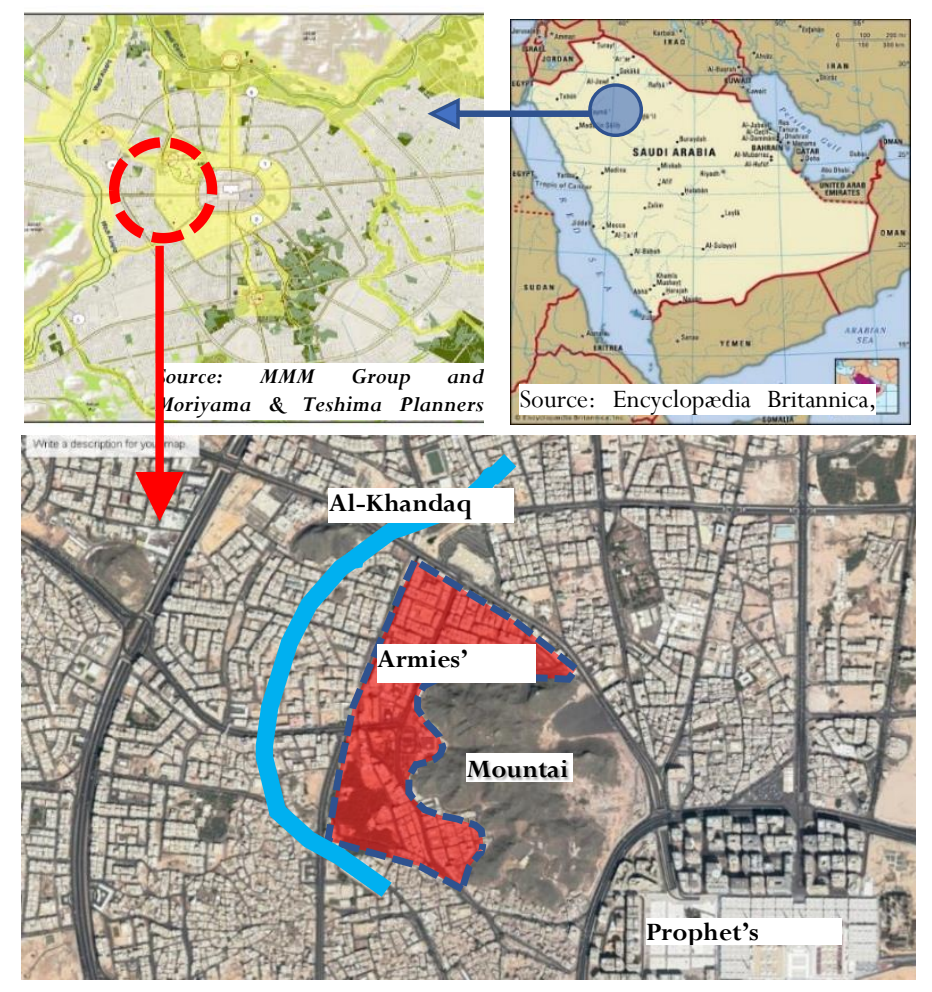

Figure 1 Location of Al-khandaq Battle in Saudi Arabia (Source: Google Earth December 2019)

\subsection{Data Collection}

People's motivations, experiences, and perceptions are the central core of this paper. In this regard, the researchers have conducted semi-structured interviews to get the visitors' perceptions. As argued by many (e.g., Cobbinah \& Aboagye, 2017; Wehrmann, 2012), semi-structured interview conversations create an opportunity for researchers to examine the phenomenon under investigation in detail, thus presenting sufficient flexibility in addressing various dimensions of the research. Interviews involved 42 persons from several countries, including Saudi Arabia, Yamen, Egypt, Jordan, Nigeria, as well as Malaysia. The interviews were conducted by the five authors of this research from Egypt, Saudi Arabia, Malaysia and Nigeria. The interviews were collected during the fieldwork from $2^{\text {nd }}$ to $22^{\text {nd }}$ December 2019. They were guided by a list of open questions that focus on the perception about the site of the battle and the values that motivate them to visit Al-Khandaq site and what they expect to see if they will explore the site after the development. Participants were interviewed using the face-to-face approach, which clarifies the purpose and objectives of the research and galvanizes their interest and relevant responses. A checklist of questions guided the interviews. It also integrated some semi- structured interviews with investigating questions (Al Jarah et al., 2019).

A pilot study has been conducted from $18^{\text {th }}$ to $28^{\text {th }}$ November 2019. The authors of this research administered the interview to all participants, in which an initial semi-structured interview was carried out with ten people to gauge their understanding of the questions. The feedback was essential to develop the questions before the meetings with all participants was carried out. Two questions have been developed regarding the frequency of visiting the seven mosques site and Al-Khandaq battle area in order to investigate the reliability of the results. During the interviews, the answers and discussions were recorded in a notebook (Wahyudi, 2017).

\subsection{Data Analysis}

The interviews were conducted in Arabic and English languages. Thus, the obtained data were transcribed and documented according to the respondents. The interview conversations were analyzed using NVivo 12 pro software (NVivo qualitative data analysis software) to generate themes and categories and ensure that the interviews' findings reflected the respondents' 
perspectives. Efficacy and reliability were ensured by arranging and contrasting the results from all respondents. According to (Cobbinah \& Aboagye, 2017), this process is useful in addressing gaps and inconsistencies that occur in the data analysis process.

\section{Results and Discussion}

Interviews involved 42 participants from six countries, namely Saudi Arabia, Yamen, Egypt, Jordan, Nigeria, as well as Malaysia. The respondents' ages ranged from 20 to 55 years old. The male represented $81 \%$ and the rest were female. Foremost, the study reveals that only $40 \%$ of respondents had visited the Al-Khandaq battle site before. Some of the respondents have misperceptions or incorrect information about the battle location. For example, when the researcher asked a respondent about the location of the battle, he said: "It is located far away from the prophet's (PBUH) Mosque, I mean out of the city boundary."

Some of the respondents who claimed they had visited Al Khandaq site could not identify the battle site, and some of them could not distinguish between Al-Khandaq and another battle named Uhud located in the north of Al-Haram.

On the other hand, $57 \%$ of the respondents stated that they had previously visited the Seven Mosques' site. This implies that several participants do not know the location of Al-Khandaq

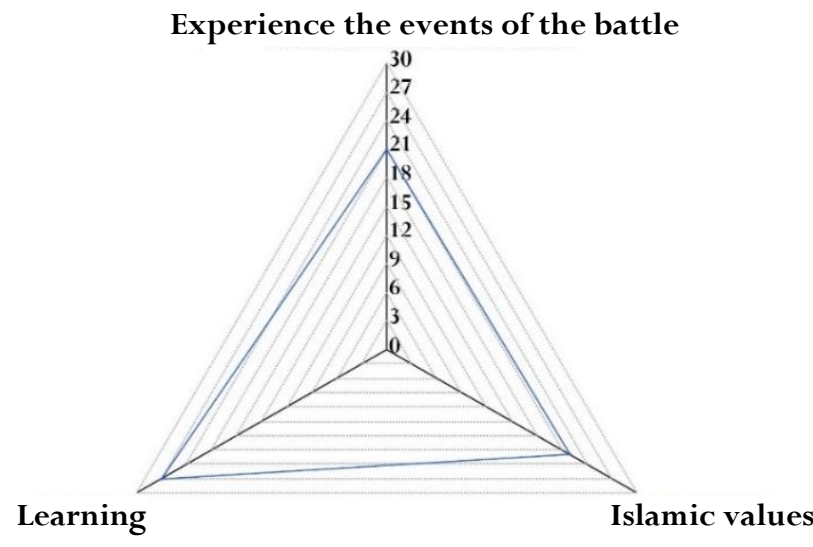

(a) Results of coding references analysis battle site, as well as the history of the Seven Mosques, which is located in the center of Al-Khandaq battle site.

The respondents refer to the three following reasons for their not visiting the site of Al-Khandaq battle: the lack of arranged tours to this place, the inadequacy of signages leading to this site, and outright ignorance of the location.

\subsection{The Motivation To Visit The Site}

In this part, the primary intent is to address the first objective, and to achieve that, the following research question was posed: "What motivates you to visit the battle site?". In view of this, (Figure 2-a) shows that a total of 70 codes were created from the answers. From the analysis of the coding reference in NVivo, $38.6 \%$ of respondents were of the view that learning purpose was the main reason behind the visit. For example, one of the interviewees reported that "learning through exploration is to move from fiction and stories to reality." A further $31.4 \%$ and $30 \%$ were of the view that experiencing the events of the battle, and Islamic values, respectively, were the main motivations to their visiting the site. On the other hand, using the words coded analysis tool, the Islamic values got the highest priority with $42.9 \%$, followed by experiencing the events of the battle with $29.4 \%$, and finally, learning purposes with $27.8 \%$ (see Figure 2 b).

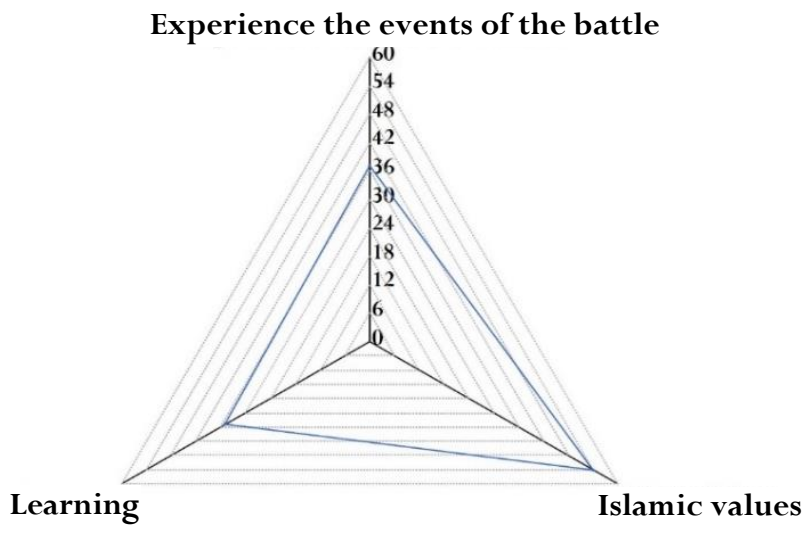

(b) Results of words coded analysis

Figure 2 Visitors' motivations to visit the site

From the previous results, learning purpose code ranked first based on code references, whereas Islamic values got the highest level on word coded test, which means the interviewees gave much explanation on the importance of Islamic values. There is no conflict between the results from both tests, as people are concerned about visiting the site in order to acquire more knowledge in terms of Islamic perspectives. This is a significant finding in understanding what motivates people to visit AlKhandaq battle site.

\subsection{Visitors Expectations}

This section tries to identify the expectation of the visitors to the site. The following question was designed, "What would you expect to see there?". Given this, Figure 3-a illustrates that a total of 50 codes were generated from the visitors' responses. Among them, $50 \%$ were expecting that the site would have contained a historical museum. One of the visitors pointed out that "I expect an open museum showing events of the foray, the tents of the polytheists' army, and the types of weapons have been used in the battle." A significant 28\% expected the body of Al-Khandaq path, and the rest (22\%) highlighted the accessibility to the site from the Prophet Mosque. Using words coded analysis has 
corroborated similar trends of the open historical museum, which scored $57.6 \%$ followed by the accessibility to the site with $27.1 \%$, then Al-Khandaq path with the lowest rate of $15.2 \%$ (see Figure 3-b).

The historical open museum code has taken a significant proportion (i.e.50\%) of the code words from the visitors' respondents. They suggest developing the site as an open-air museum reflecting the real actions of the battle flow as they studied in books. Even though the path of Al-Khandaq is considered a vital part of the museum, from the interviewees' point of view, they shed light on it and emphasized on the need for it to be reconstructed. Accessibility to the site is the third expectation of the visitors. Considering their answers, especially

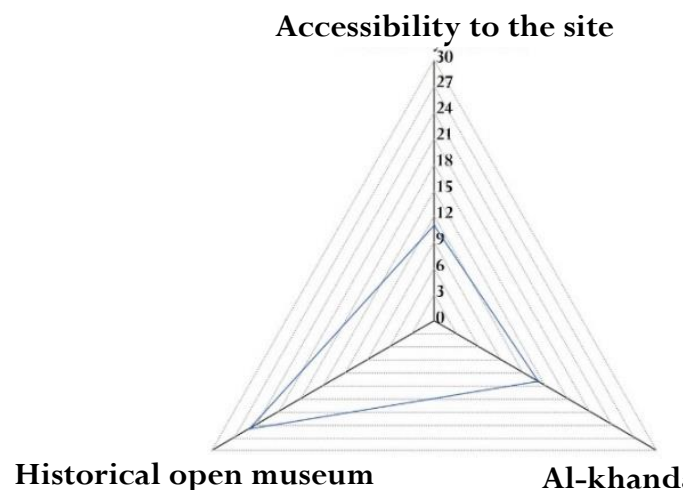

Historical open museum

Al-khandaq path Historical open museum those who did not visit the site, they said they did not know that the site is nearby AL-haram, as no signage offered guidance to the site. It is worth noting that many of those who had visited the seven mosques did not realize that the location is the Al-Khandaq battle site. Besides, they had to walk through low-quality residential areas and cross some not walk-friendly roads to reach the site. The foregoing's lateral imports are that the primary desire to learn more about the battle's religious history can be achieved by transforming the site into an open museum.

(a) Results of coding references analysis

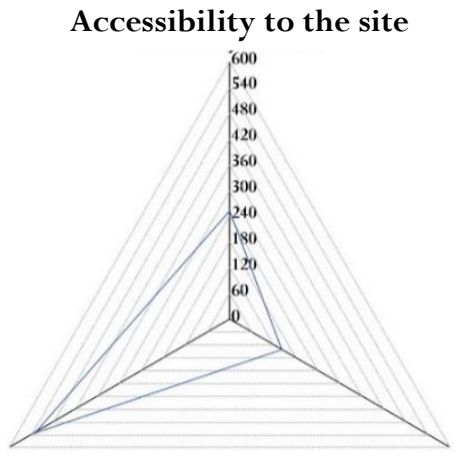

Al-khandaq path

Figure 3 The visitors' expectation about the site

\subsection{Visitors Perceptions}

This part aims to understand the visitors' perceptions of the proper way to rehabilitate the site. The question was designed as thus: "What is your perception of the ideal way to develop the site?" The results from the analysis of the coding references show that (see Figure 4-a) most visitors thought Al-Khandaq Path needed to be dug up again. This factor scored $30.8 \%$ out of the total codes. One of the interviewees said: "I would like to see the body of the trench, as it is a crevice in the ground of great length and width that horses cannot easily cross." The next factor, which weighted $23.1 \%$, is the historical site, as the visitors emphasized that the importance of the pattern of the site should be developed traditionally to reflect the spirit of the battle. Then, the Army Camps scored $17.9 \%$ of visitor interest, as they were keen to see the exact spots of the Muslims' tents as well as the non-Muslims' camp. The fourth factor is the tourist attractions, with $15.4 \%$. The respondents mentioned the importance of tourist attractions services (e.g., souvenirs markets, hotels, and traditional cuisines) - lastly, the vast land and Mountain with $12.8 \%$. The interviewees underlined the significance of paving the battleground and the role of the Mountain, which was used to shield the Muslim armies back.

There is some modification of the results noticed when using the words coded analysis. Figure 4-b displays that the Al-Khandaq path still has priority with $30.7 \%$, whereas the army camps were the second element with $24.6 \%$. Finally, $21.5 \%, 18.7,4.6 \%$ were of the view that historical sites, tourist attractions, and vast land and Mountain, respectively, were significant.

The figure shows that the most significant components of the open museum consist of three main sections. The first one is the Al-Khandaq path, which should be developed as it used to be during the prophet era. Second, army camps for both Muslims and nun-Muslims follow a separate route to the tents. Third, the border of the battle site, including the Mountain situated on the opposite side of the Al-Khandaq path, played an essential role in the battle's Muslim army strategy. Next, the tourist attraction spots should be included as they are considered a vital component for attractive destinations. Finally, all these developments should have unique characteristics by involving the historical and traditional dimensions in planning and design levels. 


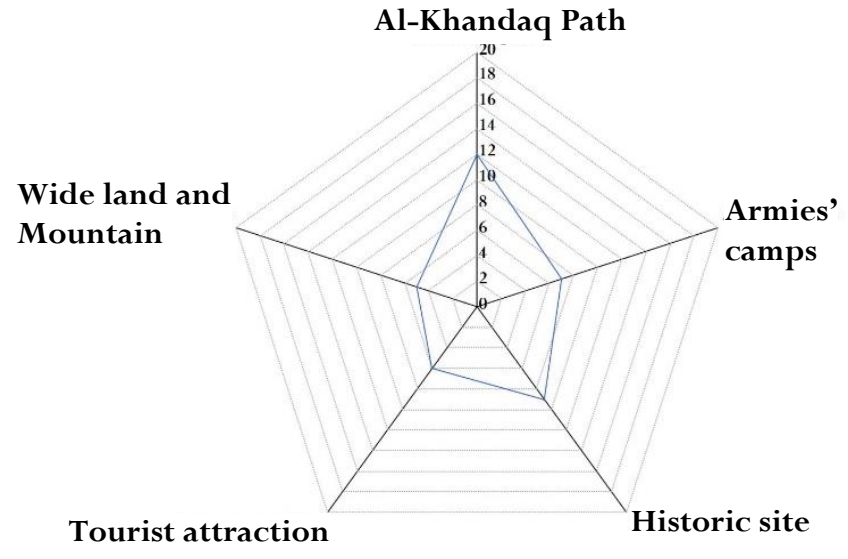

(a) Results of coding references analysis

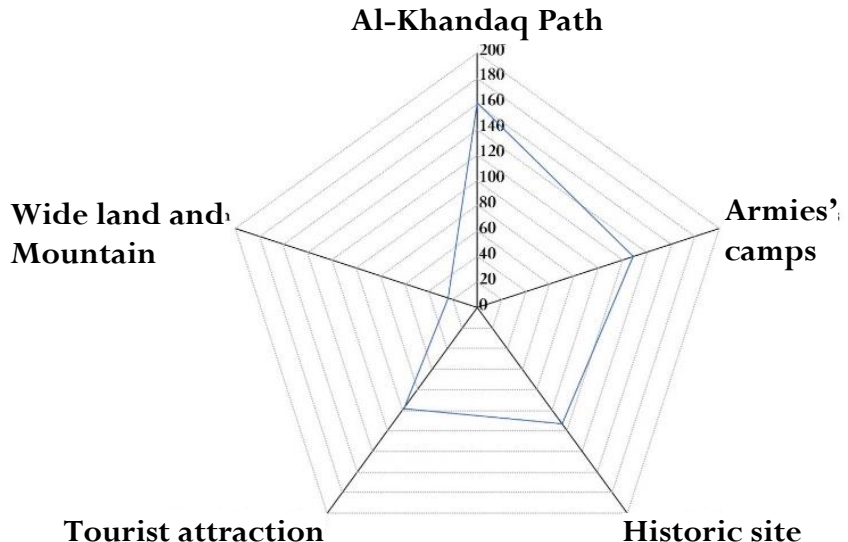

(b) Results of words coded analysis

Figure 4 The visitors' perception of the site development

\section{Conclusion}

Regarding the research aim and objective, which are to identify and investigate the influential factors enriching the tourists' experience at Religious Historical Sites (RHS), the findings and conclusions asserted that the visitors to the religious and historical places, specifically Al-Khandaq battle site, are motivated by three significant factors, which are learning purposes, Islamic values, and the need to experience the events of the battle. It was found that three significant factors enriched the Visitors' experience when they visited the RHS. Through their expectations, as the site witnessed many significant events since the earliest years of Islam, the site development plan should propose the elements reflecting the spirit of the place, utilizing the physical path of the Al-Khandaq, open museum with secure access to the site from the prophet's mosque. The visitors also acknowledge that the site has the potential to become an attractive tourist religious place in the Al-Madinah tourist attraction map. It is one of a kind, which has the characteristic of describing a critical period of Islamic history. According to the interviewees' perception, the battle site should be appropriately developed to reflect the experiences of preparing the battle and action during the battle and the implications of the outcome to enrich the visitors' experiences no matter where they come from and their languages. Building the actual body of Al-Khandaq alongside the camps of both the Muslims and non-Muslims considering the site boundary, which includes the Mountain behind the Muslim camp, could be useful in reproducing the place's memory. The connection between the site and Al-haram should also be developed and paved with traditional and local landscape elements connected with tourist attractions.

Lastly, these research findings fill the knowledge gap in developing tourism attraction sites based on the tourists' decisions in Al-Madinah and all the RHS.

\section{Acknowledgments}

The authors would like to thank the Deanship of Scientific Research and Prince Khalid Al-Faisal Chair for Developing Makkah Al-Mukarramah and the Holy Places at Umm Al-Qura University (project \# DSRUQU.PKC-42-10) for the logistics and financial support.

\section{References}

Ahmed, Z. U. (1992). Islamic pilgrimage (Hajj) to Ka'aba in Makkah (Saudi Arabia): an important international tourism activity. Journal of Tourism Studies. 3: 35-43.

Al-Ghamdi, K. A., Karban, A. S., Said, I., Rasidi, M. H., \& Al-Ghamdi, S. A. (2021). Enrich Pilgrims Experience by Improving the Wayfinding System in (Meeqat Zul Halifa) Abiar Ali. The 20th Scientific Forum for the Hajj, Umrah, and Visit Research. 427-436. Makkah: Umm Al-Qura University.

Al Jarah, S. H., Zhou, B., Abdullah, R. J., Lu, Y., \& Yu, W. (2019). Urbanization and Urban Sprawl Issues in City Structure: A Case of The Sulaymaniah Iraqi Kurdistan Region. Sustainability (Switzerland), 11(2): 2-21 https://doi.org/10.3390/su11020485

Alabau-Montoya, J., \& Ruiz-Molina, M.-E. (2020). Enhancing visitor experience with war heritage tourism through information and communication technologies: evidence from Spanish Civil War museums and sites. Journal of Heritage Tourism, 15(5): 500-510.

Allen, N. (2016). Quality of Urban Life and Intensification: Understanding Housing Choices, Trade-Offs, and the Role of Urban Amenitie. The University of Auckland.

Alsini, I., Ekiz, E., \& Hussain, K. (2019). The Impact of Umrah Quality Attributes on Religious Tourist Loyalty in Saudi Arabia. In A. Jamal, R. Raj, \& L. Griffin (Eds.), Islamic tourism: management of travel destinations. 91-109. https://doi.org/10.1080/1743873X.2019.1658351 
Baggio, R. (2008). Symptoms of complexity in a tourism system. Tourism Analysis, 13: 1-20. https: //doi.org/10.3727/108354208784548797

Bargeman, B., \& Poel, H. van der. (2006). The Role of Routines in the Vacation Decision-Making Process of Dutch Vacationers. Tourism Management, 1(4): 707-720. https:/ / doi.org/10.1016/j.tourman.2005.04.002

Battour, M., Ismail, M. N., Battor, M., \& Awais, M. (2017). Islamic tourism: an empirical examination of travel motivation and satisfaction in Malaysia. Current Issues in Tourism, 20(1): 50-67. https: / / doi.org/10.1080/13683500.2014.965665

Bian, X., \& Moutinho, L. (2015). An Investigation of Consumers' Perceptions of Counterfeit Branded Products, Original Branded Products and Purchase Intention. In Journal of Business Research. 62: 218 218. https: / / doi.org/10.1007/978-3-319-18687-0_85

Bob, M., Rahman, N., Elamin, A., \& Taher, S. (2016). Rising Groundwater Levels Problem in Urban Areas: A Case Study from the Central Area of Madinah City, Saudi Arabia. Arabian Journal for Science and Engineering. 41: 1461-1472. https://doi.org/10.1007/s13369015-1976-3

Budeanu, A. (2007). Sustainable tourist behaviour ? a discussion of opportunities for change. International Journal of Consumer Studies, 31(5): 499-508. https: / /doi.org/10.1111/j.1470-6431.2007.00606.x

Chandler, J. A., \& Costello, C. A. (2002). A Profile of Visitors at Heritage Tourism Destinations in East Tennessee according to Plog's Lifestyle and Activity Level Preferences Model. Journal of Travel Research. 41(2): 161-166. https://doi.org/10.1177/004728702237416

Chen, X., Cheng, Z., \& Kim, G.-B. (2020). Make It Memorable: Tourism Experience, Fun, Recommendation and Revisit Intentions of Chinese Outbound Tourists. Sustainability. 12(5): 1904.

Cobbinah, P. B., \& Aboagye, H. N. (2017). A Ghanaian Twist to Urban Sprawl. Land Use Policy, 61: 231-241. https://doi.org/10.1016/j.landusepol.2016.10.047

Cohen, S. A., Prayag, G., \& Moital, M. (2014). Consumer behaviour in tourism: Concepts, influences and opportunities. Current Issues in Tourism, 17(10): 872-909. https://doi.org/10.1080/13683500.2013.850064

Correia, A., \& Kozak, M. (2016). Tourists' shopping experiences at street markets: Cross-country research. Tourism Management, 56, 8595. https://doi.org/10.1016/j.tourman.2016.03.026

Costa, L. da F., \& Baggio, R. (2009). The web of connections between tourism companies: Structure and dynamics. Physica A: Statistical Mechanics and Its Applications. 388: 4286-4296. https: / /doi.org/10.1016/j.physa.2009.06.034

de Rojas, C., \& Camarero, C. (2008). Visitors' Experience, Mood And Satisfaction In A Heritage Context: Evidence From An Interpretation Center. Tourism Management. 29(3): 525-537. https://doi.org/10.1016/j.tourman.2007.06.004

Dimanche, F., \& Havitz, M. E. (1995). Consumer Behavior and Tourism: Review and Extension of Four Study Areas. Journal of Travel \& Tourism $\quad$ Marketing. 3(3): 37-57. https://doi.org/10.1300/J073v03n03_03
Eccles, J. S., \& Wigfield, A. (2002). Motivational Beliefs, Values, and Goals. Annual Review of Psychology, 53(1): 109-132. https://doi.org/10.1146/annurev.psych.53.100901.135153

Fernández-Morales, A., Cisneros-Martínez, J. D., \& McCabe, S. (2016). Seasonal concentration of tourism demand: Decomposition analysis and marketing implications. Tourism Management, 56: 172-190. https: / / doi.org/10.1016/j.tourman.2016.04.004

Frias, A., Cabral, J., \& Costa, Á. (2015). Modeling Movement of Tourists: Tools and Application in São Miguel Island, Portugal. Asian Journal of Business and Management, 3(06): 440-448.

Giddy, J. K., \& Webb, N. L. (2018). Environmental attitudes and adventure tourism motivations. GeoJournal, 83(2): 275-287. https: / / doi.org/10.1007/s10708-017-9768-9

Gnoth, J. (1997). Tourism motivation and expectation formation. Annals of Tourism Research, 24(2): 283-304. https://doi.org/10.1016/s0160 7383(97)80002-3

Griffin, K. A., \& Raj, R. (2017). The Importance of Religious Tourism and Pilgrimage: Reflecting on definitions, motives and data. International Journal of Religious Tourism and Pilgrimage, 5(3): ii-ix. https: / / doi.org/10.21427/D7242Z

Hassani, A., \& Moghavvemi, S. (2019). Muslims' travel motivations and travel preferences: The impact of motivational factors on Islamic service, hedonic and product preferences. Journal of Islamic Marketing, (June). 11(2): 344-367. https://doi.org/10.1108/JIMA-11-2018-0215

Hyde, K. F., \& Lawson, R. (2003). The Nature of Independent Travel. Journal of Travel Research, 42: 13-23.

Juhanda. (2019). Islamic local tourism activities: enriching the spirit of togetherness. ICOGISS 2019, 1(1): 174-181.

Kala, N. (2008). Host Perception of Heritage Tourism Impact with Special Reference to the City of Jaipur. South Asian Journal of Tourism and Heritage. 1(1): 65-74.

Karban, A., Jusan, M., Hussein, A. H., \& Al-Aboud, N. (2017). The Roles of Residents of Makkah during Haj and Their Influences on Housing Design - a state of art review. The 17th Scientific Forum for the Reseach of Hajj, Umrah and Madinah Visit, Scientific Portalfor 1438 AH, 116-131. Al-Madinah, Saudi Arabia: custodian of the two holy mosques institute for hajj and umrah research, Umm Al-Qura University.

Karban, A. S., Jusan, M. B. M., Hussein, A. H., \& Al-aboud, N. S. (2018). The Historical Development of Hospitality in Makkah. International Journal of Engineering \& Technology. 7: 225-229.

Lai, E. R. (2011). Motivation : A Literature Review Research. Research Reports, (April), 43. https: / / doi.org/10.2307/3069464

Li, T. E., \& McKercher, B. (2016). Developing a typology of diaspora tourists: Return travel by Chinese immigrants in North America. Tourism Management, 56: 106-113. https://doi.org/10.1016/j.tourman.2016.04.001

Lunenburg, F. C. (2011). Expectancy Theory of Motivation : Motivating by Altering Expectations. International Journal of Business Administration. 15(1): 1-6. 
McCabe, S. (2001). The Problem of Motivation in Understanding the Demand for Leisure Day Visits. Journal of Travel \& Tourism Marketing, 10(1): 107-113. https://doi.org/10.1300/J073v10n01_07

McIntosh, A. J., \& Thyne, M. A. (2005). Understanding tourist behavior using Means-End Chain theory. Annals of Tourism Research. 32: 259-262. https://doi.org/10.1016/j.annals.2004.05.005

Moscardo, G., \& Murphy, L. (2014). There is no such thing as sustainable tourism: Re-conceptualizing tourism as a tool for sustainability. Sustainability (Switzerland), 6(5): 2538-2561. https://doi.org/10.3390/su6052538

Mujtaba, U. S. (2016). Ramadan: The month of fasting for Muslims, and tourism studies - Mapping the unexplored connection. Tourism Management Perspectives, 19: 170-177. https://doi.org/10.1016/j.tmp.2015.11.001

Paker, N., \& Vural, C. A. (2016). Customer segmentation for marinas: Evaluating marinas as destinations. Tourism Management. 56: 156-171. https://doi.org/10.1016/j.tourman.2016.03.024

Pestana, M. H., Parreira, A., \& Moutinho, L. (2019). Motivations, emotions and satisfaction: The keys to a tourism destination choice. Journal of Destination Marketing and Management, (December 2018), 100332. https://doi.org/10.1016/j.jdmm.2018.12.006

Pons, F., Giroux, M., Mourali, M., \& Zins, M. (2016). The Relationship Between Density Perceptions and Satisfaction in the Retail Setting: Mediation and Moderation Effects. Journal of Business Research, 69(2): 1000-1007. https://doi.org/10.1016/j.jbusres. 2015.09.005

Poor, S. J. A. (2014). Housing needs and preferences based on maslow's motivational theory. Universiti Teknologi Malaysia. (Thesis)

Qurashi, J. (2018). Spiritual or Tourist Experience? A Critical Exploration of the Consequences of the Commodification of the Hajj on the Pilgrim Experience. University of Central Lancashire.

Rahman, M. K. (2014). Motivating factors of Islamic Tourist's Destination Loyalty: An Empirical Investigation in Malaysia. Journal of Tourism and Hospitality Management, 2(1): 63-77.

Raj, R., \& Bozonelos, D. (2015). Pilgrimage Experience and Consumption of Travel to the City of Makkah for Hajj Ritual. International Journal of Religious Tourism and Pilgrimage, 3(1): 38-45.
Rosyada, D., Mufraini, M. A., Suherlan, A., Harmadi, H., \& Supriyono, S. (2018). Promoting islamic values to encourage labour performance and productivity: Evidence from some Indonesian industries. International Journal of Business and Society, 19(95): 591-604.

Said, J., \& Maryono, M. (2018). Motivation and Perception of Tourists as Push and Pull Factors to Visit National Park. E3S Web of Conferences, 31, 08022. https://doi.org/10.1051/e3sconf/20183108022

Sharpley, R. (2018). Tourism, Tourists and Society. In Routledge. UK: Elm Publications.

Stylidis, D., Biran, A., Sit, J., \& Szivas, E. M. (2014). Residents' support for tourism development: The role of residents' place image and perceived tourism impacts. Tourism Management, 45: 260-274. https://doi.org/10.1016/j.tourman.2014.05.006

Thai, V. (2015). Determinants of customer expectations of service :Implications for fostering customer satisfaction. International Journal of Management and Applied Science, 1(4): 7-12.

Wahyudi, A. (2017). Modelling Urban Growth: Integrating Both Physical and Human Dimensions in Developing World Context.

Wehrmann, B. (2012). Land Use Planning Concept, Tools and Applications. In Eschborn, Germany, GIZ. Retrieved from www2.gtz.de/dokumente/bib-2011/giz2011-0041en-land-useplanning.pdf.Retreived on April 2020

Yawson, D. O., Armah, F. A., \& Pappoe, A. N. M. (2009). Enabling sustainability: Hierarchical need-based framework for promoting sustainable data infrastructure in developing countries. Sustainability, 1(4): 946-959. https://doi.org/10.3390/su1040946

Zakariya, K., Haron, R. C., Tukiman, I., Rahman, S. A. A., \& Harun, N. Z. (2020). Landscape Characters for Tourism Routes: Criteria to Attract Special Interest Tourists to The Kuala Selangor-Sabak Bernam Route. Planning Malaysia, 18(14): 430-441.

Zeithaml, V. A., Berry, L. L., \& Parasuraman, A. (1993). The nature and determinants of customer expectations of service. Journal of the Academy of Marketing Science, 21(1): 1-12. https://doi.org/10.1177/0092070393211001

Zhang, X., Yang, Y., Zhang, Y., \& Zhang, Z. (2020). Designing Tourist Experiences Amidst Air Pollution: A Spatial Analytical Approach Using Social Media. Annals of Tourism Research, 84: 102999. 